\title{
O USO DO CROMO DURO NA LANINAÇÃO DE COBRE PARA AUMENTO DA CAMPANHA DO CIINDRO DE TRABALHO A FRIO (1)*
}

\author{
Antonio Fabiano de Oliveira ${ }^{1}$ \\ Guilherme Frederico Bernardo Lenz e Silva ${ }^{2}$ \\ Ronald Lesley Plaut ${ }^{3}$ \\ Ricardo Lívio Ferreira Oliveira ${ }^{4}$
}

\section{Resumo}

Estudos de laminação com revestimento de cromo e influência nas propriedades foram realizados com o objetivo de aumentar a produtividade dos cilindros. Para tal, foram utilizados cilindros cromados para laminação de chapas de cobre, com amostragem da técnica de réplica epoxy. A compreensão da correlação entre microestrutura e propriedades do material é objeto de grande interesse e, ao mesmo tempo, necessário para aplicação prática na laminação a frio, combinando revestimento e produtividade. O objetivo da pesquisa atual é comparar as propriedades tribológicas do cobre antes e depois da laminação, no cilindro de trabalho e chapa, com e sem revestimento de cromo.

Palavras-chave: Desgaste; Laminação de Cobre; Rugosidade 3D

\section{THE USE OF HARD CHROMIUM PLATING IN ROLLING OF COPPER FOR INCREASING CAMPAIGN LENGTH OF COLD MILL WORK ROLLS (1)}

\section{Abstract}

Studies of rolling with chrome coating and influence on properties were carried out with the aim of increasing the productivity of mills. Therefore, were used rolling with chrome coating for sheet copper, with sampling the replica epoxy technique. The understanding of the correlation between microstructure and properties of material is subject of great interest, and, in the same time, necessary for practical application in the cold mill, combining coating and productivity. The aim of current research is comparison between tribological properties of copper before and after rolling used work rolls with and without chromed coating.

Keywords: Wear; Copper Cold Mill; 3D Roughness

\footnotetext{
Metallurgical Engineer, PhD student USP; manager CRC do Sul Mauá

Metallurgical Engineer, PhD and Prof. Dr. USP SP

Metallurgical Engineer, PhD and Prof. Dr. USP SP

Metallurgical Engineer, Director CRC do Sul
} 


\section{INTRODUÇÃO}

The main objective of the research was to obtain the maximum benefits from the claimed advantages of hard chromium plating in cold mills used for the production of sheet gauge cold rolled steel strip. In particular, the surface texture of cold reduced strip is continually being required to be improved at the request of customers. Such demands have meant an increased number of roll changes, loss of production time and thus increased costs. New technologies are always offering coating over the rolls for use in cold rolling mills and it has been claimed that these rolls will give longer runs between roll changes thereby leading to more consistent strip texture and reduced production costs [1].

The use of hard chromium on the rolls in the copper cold mill was examined, to compare the performance of this technique with that of conventional no-chromed work rolls. The major areas of the investigation included roll preparation, grinding, mill performance and the transfer of texture from roll to strip. A major part of the research involved the development of epoxy replica, which could measure surface texture of both roll and strip to give a complete description in surface topography terms [1].

\subsection{Effect of cold rolling on the hardness of copper}

The effect of severe cold working on the properties, particularly on the hardness, of metals such as copper has been the subject of extended discussion. It is common knowledge that moderate amounts of cold work materially increase the hardness and tensile strength of many metals, but that an excessive amount of cold work may result in the development of internal or external structural defects, which seriously impair the mechanical properties [2].

Several years ago Rawdon and Mutchler [2] interpreted results of hardness measurements of severely cold-rolled strips of copper as indicating the attainment of maximum hardness after a moderate amount of reduction by cold-rolling, after which further reduction was accompanied by a progressive decrease in hardness.

\subsection{Ranges of industrial application}

In a series of applications, three-dimensional surface roughness analysis has been found to be a powerful and versatile concept, compared to two-dimensional profilometry used in connection with visual inspection through a microscope [4]. Some examples of industrial applications of three-dimensional surface analysis related to the following functional features are presented here [5]:

a) Leakage and wear on seals

b) Wear on deep drawing dies

c) Paintability of sand blasted surfaces

d) Efficiency of cutting fluids

\subsection{D surface topography analysis}

The roughness characterization of technical surfaces based on 2D description is not quite satisfactory for many industrial applications. Therefore, with rapid development with new measuring methods based on powerful computer generation techniques in Figure 1, and introduction of 3D surface parameters into research and industry is taking place [6]. 


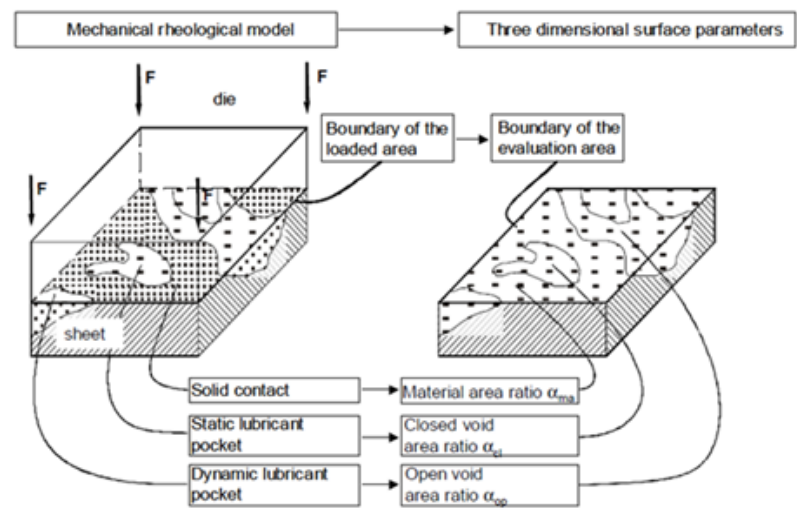

Figure 1: Derivation of three-dimensional surface parameters from mechanical/rheological model [6]

As shown in Figure 2, relative amount of solid contact corresponds to material area ratio. 3D surface parameters for static and dynamic lubricant pockets are closed void area ratio and open void area ratio [6]. Material area ratio has already been introduced by Stout [7] as a useful tool for comparative analysis of surfaces, based upon a three-dimensional measurement of surface.

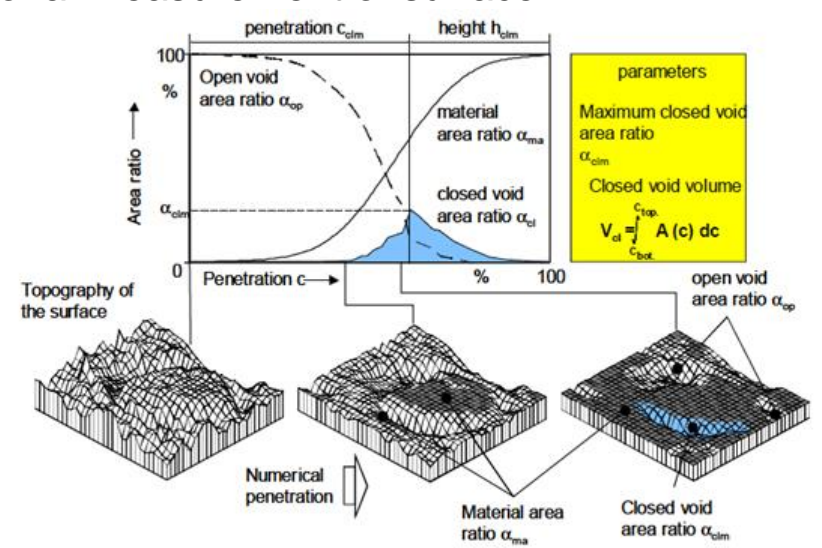

Figure 2: Material ratio, as well as the open and closed void ratio using the example of the lubricant crater of a Lasertex surface and definition of vertical parameters according to [7].

\subsection{Temper Mill Reduction}

After roll texturing process has been finished, the roll-surface structure has to be transferred to the sheet metal. This process is obtained through Temper Mill (TM). Previous studies have been performed on the transfer characteristics of different work roll surfaces onto the sheet metal in terms of TM reductions [8].

Practical data obtained from Temper mills have shown a fivefold increase in roll life (measured via decrease in Ra values) of texturized Cr-plated rolls [9]. Furthermore, Simão and Aspinwaal, have shown that roll performance is function of roll roughness, see Figure 3 [10]. It may be observed that as roll roughness decreases slightly, there will be a gain in roll life, if the wear of the roll roughness is associated with friction issue. This difference in roll life related to roll roughness has been associated with breaking of roll roughness peaks [10]. Authors could not find any information related to simultaneous evolution of $\mathrm{Ra}$ values for both, i.e., roll and sheet metal. This research will try to analyze this aspect. 


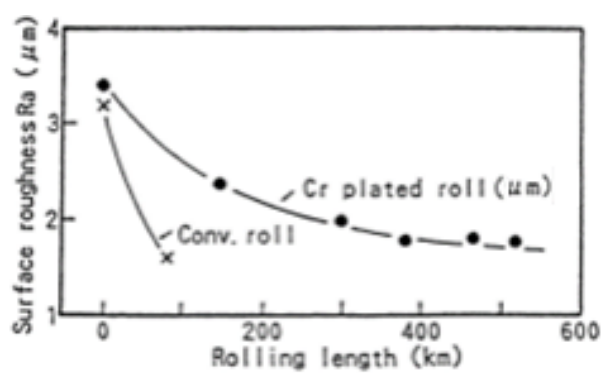

Figure 3: Comparative performance of chromium plated and temper mill rolls [10].

\subsection{Measurement Techniques}

For the past fifty years, the stylus method has been used to evaluate surface texture. Although some progress has been made in recent years with non-contact optical methods using lasers, these techniques do not yet have the resolution of the stylus method. Stylus instruments, such as the Talysurf range, transverse a diamond stylus across the surface under examination at a constant speed. The stylus is coupled to a displacement transducer, which converts the vertical movement of the stylus into an electrical signal, which represents the traced surface profile [11].

\subsection{Advantages of three-dimensional surface}

Since the mid-seventies, three-dimensional measuring systems for surface topography analysis have been developed and used at many Laboratories [5]. While the main objectives of these efforts originally were the to create network reproductions of the surfaces in three dimensions, several features as colored plots, extensive filtering facilities, compu1ation of three-dimensional parameters as well as, volume and area computation facilities have been added and are now In use, in different systems.

Figure 4 illustrates the Interaction between the three elements involved with a surface: generation, characterization and function. The three elements are Interdependent and for each specific application it is necessary to consider each aspect carefully. In normative standards, roughness and waviness are generally defined in terms of the production process used in manufacturing the component. In the last few years, however, a functional approach has become more and more common, because it has been recognized that the parameters relating to the production process are not necessarily related to specific functions [5].

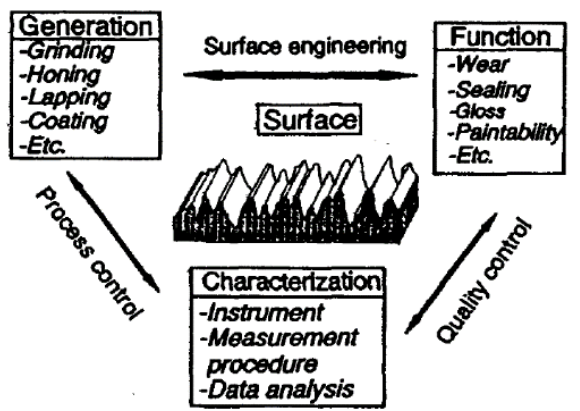

Figure 4: The three elements in surface metrology generation, characterization and function, showing the tree interrelated factor: process control, quality control and surface engineering.

Efforts has been made to relate specific features of the surface to surface's function and to develop special functional parameters, although this requires a large number of new parameters. A fundamental step in this direction is three-dimensional surface analysis. Generally, characterization of surfaces in three dimensions is needed if the 
surface comprises an inhomogeneous topography or one characterized by isolated features such as holes, ridges.

\section{METHOD AND MATERIALS}

\subsection{Replica Authentication}

Analysis of roughness over work rolls and sheet metal was made possible with support of surface replicas. A resin Zhermack colorbite D [12] was used to produce the replicas. The capability to replicate the topography was evaluated initially in this work.

Table I - Results of measured parameters between on replica and on a standard

\begin{tabular}{|c|c|c|c|c|c|c|c|c|c|c|c|}
\hline \multicolumn{3}{|c|}{ Measured on standard } & \multicolumn{3}{|c|}{ Measured with replica } & \multicolumn{3}{|c|}{ Measured on standard } & \multicolumn{3}{|c|}{ Measured with replica } \\
\hline \multicolumn{3}{|c|}{ Height Parameters } & \multicolumn{3}{|c|}{ Height Darameters } & \multicolumn{3}{|c|}{ Height Parameters } & \multicolumn{3}{|c|}{ Height Parameters } \\
\hline Sa & 0.5846 & $\mathrm{um}$ & Sa & 0.0056 & ym & $S Q$ & 6.803 & $\mathrm{~mm}$ & $S A$ & 6.096 & $\mathrm{~mm}$ \\
\hline Sak & 0.1327 & & Sak & 0.1300 & & sok & 0.1021 & & Sak & 0.07254 & \\
\hline sev & 1.558 & & Shu & 1.560 & & She & 1.702 & & She & 2.813 & \\
\hline so & 1.571 & $\mathrm{~mm}$ & So & 1.528 & um & so & 13.29 & $\mathrm{~mm}$ & So & 12.66 & $\nu \mathrm{m}$ \\
\hline So & 2.437 & $\mathrm{~m}$ & So & 1.450 & $\mu \mathrm{m}$ & So & 11.67 & $\mathrm{m}$ & So & 12.49 & $\nu \mathrm{m}$ \\
\hline so & 3009 & $\mathrm{~mm}$ & $s$ & 2.979 & um & $s$ & 24.96 & $\mathrm{~mm}$ & Sa & 25.15 & ym \\
\hline so & 0.7900 & in & so & 0.7906 & um & so & 6.004 & $\mathrm{~m}$ & so & 5.96: & $y \mathrm{~m}$ \\
\hline \multicolumn{3}{|c|}{ Functional Parameters } & \multicolumn{3}{|c|}{ Functional Parameters } & \multicolumn{3}{|c|}{ Functional Darameters } & \multicolumn{3}{|c|}{ Functional Parameters } \\
\hline $\sin$ & 32.47 & 5 & $\sin r$ & 33.75 & 5 & $\sin x$ & 0.3007 & s & $\sin x$ & 2.007 & 5 \\
\hline $\sin x$ & 2.176 & $\mathrm{~mm}$ & $\sin x$ & 1004 & $\mu \mathrm{m}$ & $\sin x$ & 9.894 & $\mathrm{~m}$ & $\sin x$ & 9.765 & $\mu \mathrm{m}$ \\
\hline$S \times 0$ & 2.142 & $\mathrm{~mm}$ & $5 \times 0$ & 1.148 & m & $5 \times 0$ & 10.45 & $\mathrm{~m}$ & $\sin 0$ & 20.53 & $\mu \mathrm{m}$ \\
\hline \multicolumn{3}{|c|}{ Functional Parameters (Volu... } & \multicolumn{3}{|c|}{ Functional Parameters (Volu... } & \multicolumn{3}{|c|}{ Functional Parameters (Volu... } & \multicolumn{3}{|c|}{ Functional Darameters (Volu. } \\
\hline $\mathrm{V}_{\mathrm{m}}$ & 0.00706 & $\mu m^{2} / / m^{2}$ & $\mathrm{~V}_{\mathrm{m}}$ & 0.006926 & $\mu m^{2} / / \mu m^{2}$ & $\mathrm{Vm}$ & 0.1266 & $\mathrm{~m} \mathrm{~m}^{2} / \mathrm{um} \mathrm{m}^{2}$ & $\mathrm{Vm}$ & 0.1251 & $\mathrm{~m} \mathrm{~m}^{2} / \mathrm{m} \mathrm{m}^{2}$ \\
\hline w & 2.267 & $4 m^{*} / u m^{*}$ & w & 1.269 & $\mu m^{2} / \nu m^{2}$ & w & 10.01 & $v m^{2} / v m^{2}$ & w & 9.590 & $\mu \mathrm{m}^{2} / \mathrm{mm^{2 }}$ \\
\hline$V m o$ & 0.00706 & $v m^{2} / u m^{*}$ & $V=0$ & 0.006926 & $\mu m^{2} / \nu m^{2}$ & $\operatorname{Vim}$ & 0.1266 & $v m^{2} / v m^{2}$ & Vimo & $0.25:$ & $\mu m^{2} / \mathrm{m}^{2}$ \\
\hline$v_{k}$ & 2.245 & $u m^{2} / u m m^{2}$ & we & 1.247 & $\mu m^{2} / / \nu m^{2}$ & we & 9.610 & $y m^{2} / / m^{2}$ & We & 9.422 & $\mathrm{nn} / \mathrm{m} \mathrm{m}^{2}$ \\
\hline $\operatorname{Vmx}$ & 2.017 & $4 \mathrm{~m}^{2} / \mathrm{mm}^{*}$ & $V=x$ & 1.020 & $\mu m^{*} / \nu m^{*}$ & $\operatorname{Vin}$ & 7.506 & umblum & $\operatorname{Vin} x$ & 7.375 & unt/um* \\
\hline$w_{w}$ & 0.02155 & $\mu m^{2} / v m$ & $w_{w}$ & 0.02173 & $\mu m^{2} / / \mu m m^{2}$ & $w_{w}$ & 0.3924 & jentivmt & $w_{w}$ & 0.4672 & $\mu m / / 2 m$ \\
\hline \multicolumn{3}{|c|}{ Feature Parameters } & \multicolumn{3}{|c|}{ Feature Parameters } & \multicolumn{3}{|c|}{ Feature Parameters } & \multicolumn{3}{|c|}{ Feature Parameters } \\
\hline sox & 0.4059 & $1 / \mu m$ & $s o x$ & 0.3862 & $1 / \mathrm{mm}$ & $S \infty x$ & 3.895 & $1 / \mathrm{mm}$ & $s a x$ & 9.450 & $1 / \mathrm{wm}$ \\
\hline sioz & 1.185 & $\mathrm{mm}$ & $\$ 10 z$ & 2.264 & $\mu \mathrm{m}$ & $510 z$ & ...... & $\mathrm{m}$ & S10z & 12.28 & $\mu \mathrm{m}$ \\
\hline 550 & 0.7447 & im & 550 & 1.117 & um & 550 & $\cdots \cdots$ & um & S50 & 4.778 & um \\
\hline SSv & 0.406 & im & Ssiv & 1.146 & $\mu m$ & S5iv & $\cdots \cdots$ & $m$ & SS: & 7.498 & um \\
\hline sde. & 5070 & unt & sdo & 726.6 & $u m^{*}$ & sos & ..... & $u^{*}$ & sdo & 85.41 & $\mu m^{*}$ \\
\hline Sho & 1090 & $\mathrm{um}^{*}$ & Sho & 440.4 & $\mathrm{unt}^{*}$ & Sho & 693.1 & $\mathrm{um}^{*}$ & Sho & 70.51 & $\mu m^{*}$ \\
\hline Sodv & 5.042 & $\mathrm{um}^{\prime}$ & Sodr & 6.006 & jm, & Sobr & ..... & um, & Sobv & 2.999 & ums \\
\hline Shr & 2.957 & vm, & Shrv & 1.975 & $\mu m^{\prime}$ & Shr & 13,44 & ym' & Shr & $2: 100$ & $\mu \mathrm{m}$ \\
\hline \multicolumn{6}{|c|}{ Standard used $=0.86 \mu \mathrm{m}$} & \multicolumn{6}{|c|}{ Standard used $=6.0 \mu \mathrm{m}$} \\
\hline
\end{tabular}

A comparative method replica resin permit to evaluate surface topography of cold mill work rolls, see Table I. Sa roughness average in both situations, original standards of 6,0 $\mu \mathrm{m}$ and 0,86 $\mu \mathrm{m}$, are compared in Table I.

From Table I, using the main roughness parameters, we obtain Table II with a high correlation coefficient, thus authenticating the replica procedure used in this project.

Table II - Results coefficient of correlation

\begin{tabular}{|c|c|c|c|c|}
\hline \multirow[b]{2}{*}{ Parameters } & \multicolumn{4}{|c|}{ Comparative evaluation of standard versus replica } \\
\hline & $\begin{array}{c}\text { Original standard } \\
\text { roughness }=0,86 \mu \mathrm{m}\end{array}$ & $\begin{array}{c}\text { Replica } \\
\text { Roughness }\end{array}$ & $\begin{array}{c}\text { Original standard } \\
\text { roughness }=6,0 \mu \mathrm{m}\end{array}$ & $\begin{array}{c}\text { Replica } \\
\text { Roughness }\end{array}$ \\
\hline $\mathrm{Sq}$ & 0,8846 & 0,8856 & 6,883 & 6,896 \\
\hline Ssk & 0,1327 & 0,13 & 0,1021 & 0,07254 \\
\hline Sku & 1,558 & 1,56 & 1,782 & 1,813 \\
\hline $\mathrm{Sp}$ & 1,571 & 1,528 & 13,29 & 12,66 \\
\hline Sv & 1,437 & 1,45 & 11,67 & 12,49 \\
\hline Sz & 3,009 & 2,979 & 24,96 & 25,15 \\
\hline Sa & 0,79 & 0,7906 & 6,004 & 5,961 \\
\hline Coefficient of correlation & 0,9998 & & 0,9987 & \\
\hline
\end{tabular}

\subsection{Replica Analysis}

The equipment to perform the replica analysis of the surface topography, using international 3D roughness parameters, is shown in Figure 5. 

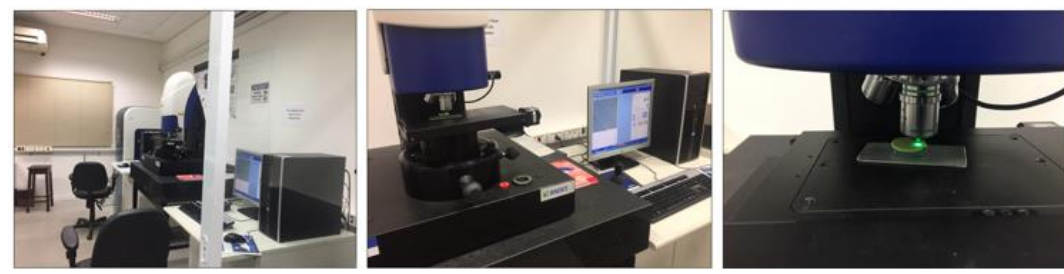

Figure 5: Image of rugosimeter 3D - Talysurf CCI [3]

2.3 Evaluation: Roughness test retention in a cold rolling

Roughness retention of a work roll chromed has been determined at four high cold mill [12]. Figure 6 shows the application of replica during sampling on rolls and on sheet.
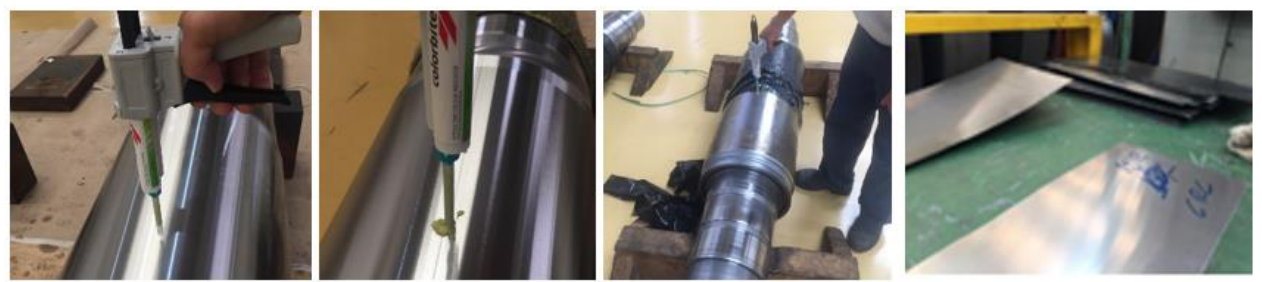

Figure 6: Application of replica on WRC/WRU and sheet at cold mill [12]

In these trials, evaluation has been performed over several work roll campaigns and on sheet metal, simultaneously. Replicas were applied on work rolls and sheet, in three roll change steps, namely: beginning (50 tons), middle (about 250 tons) and final (about 800-1300 tons), for chromed and no-chromed rolls and sheet. These steps/positions were strategically defined in order to verify wear.

Table III - Results of trials on cold mill

\begin{tabular}{|cccccc|}
\hline \multirow{2}{*}{ Trials Number } & $\begin{array}{c}\text { Roll } \\
\text { Type }\end{array}$ & $\begin{array}{c}\text { Number } \\
\text { of changes }\end{array}$ & $\begin{array}{c}\text { Average } \\
\text { tonnes rolled }\end{array}$ & $\begin{array}{c}\text { wear } \\
\mathrm{mm}\end{array}$ & $\begin{array}{c}\text { Roll wear } \\
\text { tonnes } / \mathrm{mm}\end{array}$ \\
\hline 1 & no-chromed & 36 & 75 & 0,10 & 750 \\
\hline 2 & chromed & 32 & 580 & 0,15 & 3867 \\
\hline 3 & no-chromed & 39 & 78 & 0,11 & 709 \\
\hline 4 & chromed & 37 & 820 & 0,18 & 4556 \\
\hline & no-chromed & 46 & 76 & 0,12 & 633 \\
& chromed & 83 & 1230 & 0,25 & 4920 \\
\hline & no-chromed & 12 & 80 & 0,14 & 571 \\
\hline
\end{tabular}

It can be seen from Table III that, for all the trials, a significant improvement in terms of tonnes rolled per changes and roll wear rate has been achieved with chromed rolls compared to no-chromed work rolls. On trials number 4, no-chromed rolls show a significant advantage over chromed rolls in terms of tonnes per trip though roll wear is different, but the roll wear on chromed is almost thirteen fold comparative to nochromed. In relation to wear, on average, no-chromed rolls require almost half the stock removal of chromed rolls, as stated previously. The reason for the relatively poor performance of the chromed rolls in begin of trials is that rolls in this stand are 
changed not only due to damage, but also due to loss of surface texture. It was stated previously that chromed rolls are more difficult to the high level of roughness required for this cold mill. Therefore, on average the initial roll roughness of chromed rolls entering was less than that of no-chromed rolls. Furthermore, examination of roll texture after service has shown that the texture of no-chromed rolls tends to open out and decrease more rapidly than that of chromed rolls. After the first trials, the roughness was increased and consequently increase of the average tonnes rolled.

Examination of the roll records for a five month period on this cold mill, when approximately equal numbers of chromed and no-chromed rolls were in service, has shown that of the damaged rolls $38 \%$ of the no-chromed rolls had to be reground compared to only $15 \%$ of chromed rolls. This is a significant difference, which, together with the fact that the chromed rolls had on average only half the stock removal of the no-chromed rolls, indicates that when chromed rolls are damaged in the mill the damage penetrates far less into the roll surface than with no-chromed rolls.

\subsection{Texture transfer}

The transfer of texture from roll to strip is highly complex. The most important parameter in determining strip texture is, of course, the roll texture. However, the proportion of this texture transferred can be greatly modified by the many variables involved in the rolling process. For example, the hardness of the strip entering the last pass of the cold mill depends on the grade of material and the amount of reduction given in the earlier passes. The lubricant film acts as a barrier to the transfer of texture and the thickness of the film will depend on the speed of rolling and the concentration of the fluid [7].

The pressure in the roll bite depends on the roll force, tension, roll diameter, draft, speed of rolling, width of material, and also forward slip which is very difficult to determine. In an attempt to evaluate, the effect of all the variables of cold mill was monitored for a continuous period involving 20 roll changes on last pass. The rolling variables were monitored for each coil rolled during this period. Roll textures were measured with epoxy resin, before and after service and strip samples taken for coils.

\section{RESULTS AND DISCUSSION}

\subsection{Roughness Retention Trials}

Trials have been carried out in order to evaluate roughness retention of rolls and sheet surfaces. Figure 7 shows variation of Sa values for WRC system.

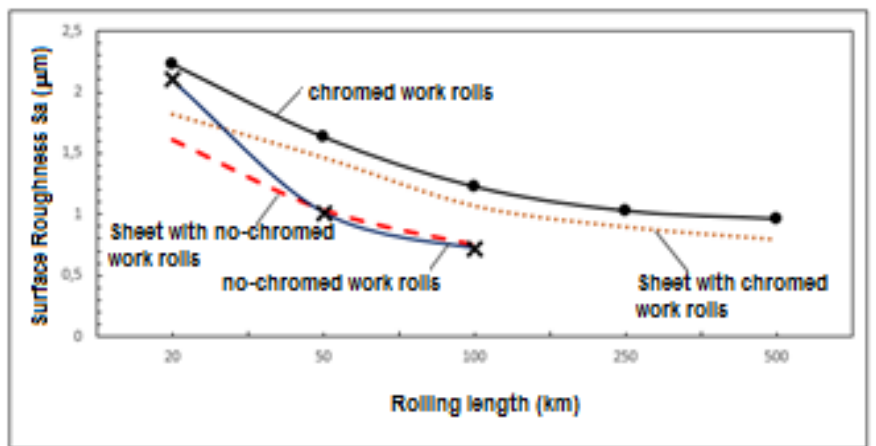

Figure 7: variation of Sa roughness of surfaces from chromed (WR Coated) rolls with rolling length compared to no-chromed (WR Uncoated) rolls, solid lines from [10], dotted lines (research for rolls), 
traced lines (research for sheet $(\mathrm{SH})$, see Fig. 6). Ra values (2D) are taken as being similar to Sa values (3D).

These results from Figure 7 show that the roughness retention curves both from [10] and those from current research show similar trend. Clearly, chromed roll showed about fivefold higher performance than no-chromed, confirming information given in Figure 3.

\subsection{Evolution of Surface Topology (on steel sheet)}

Figure 7 also shows evolution of steel sheet roughness for same conditions, which is the novel aspect of current research. Furthermore, 3D-surface topology of chromed rolls before and after applying of hard chrome may be observed in figure 8 . More details on 3D surface analysis may be obtained from [6] and [7].
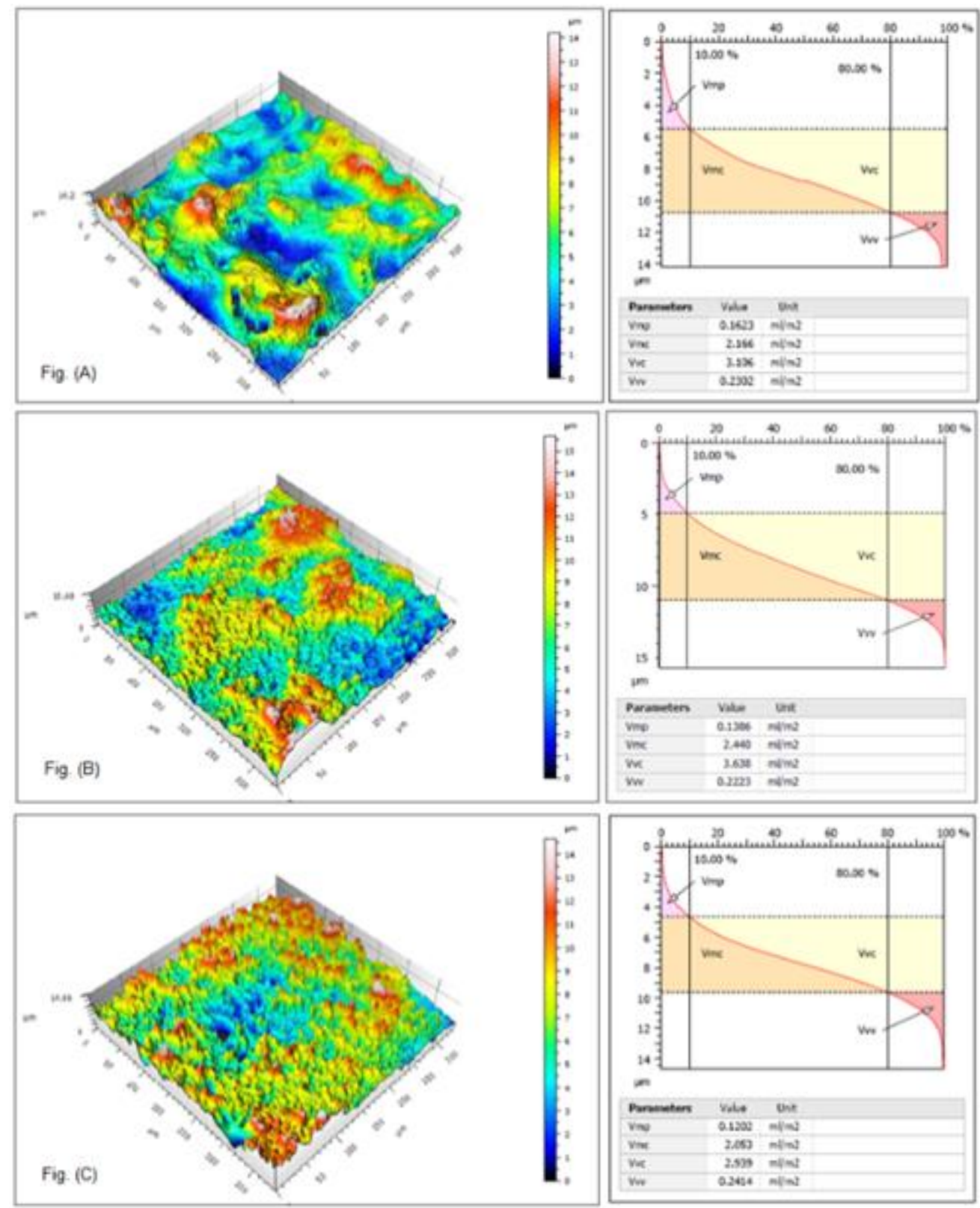

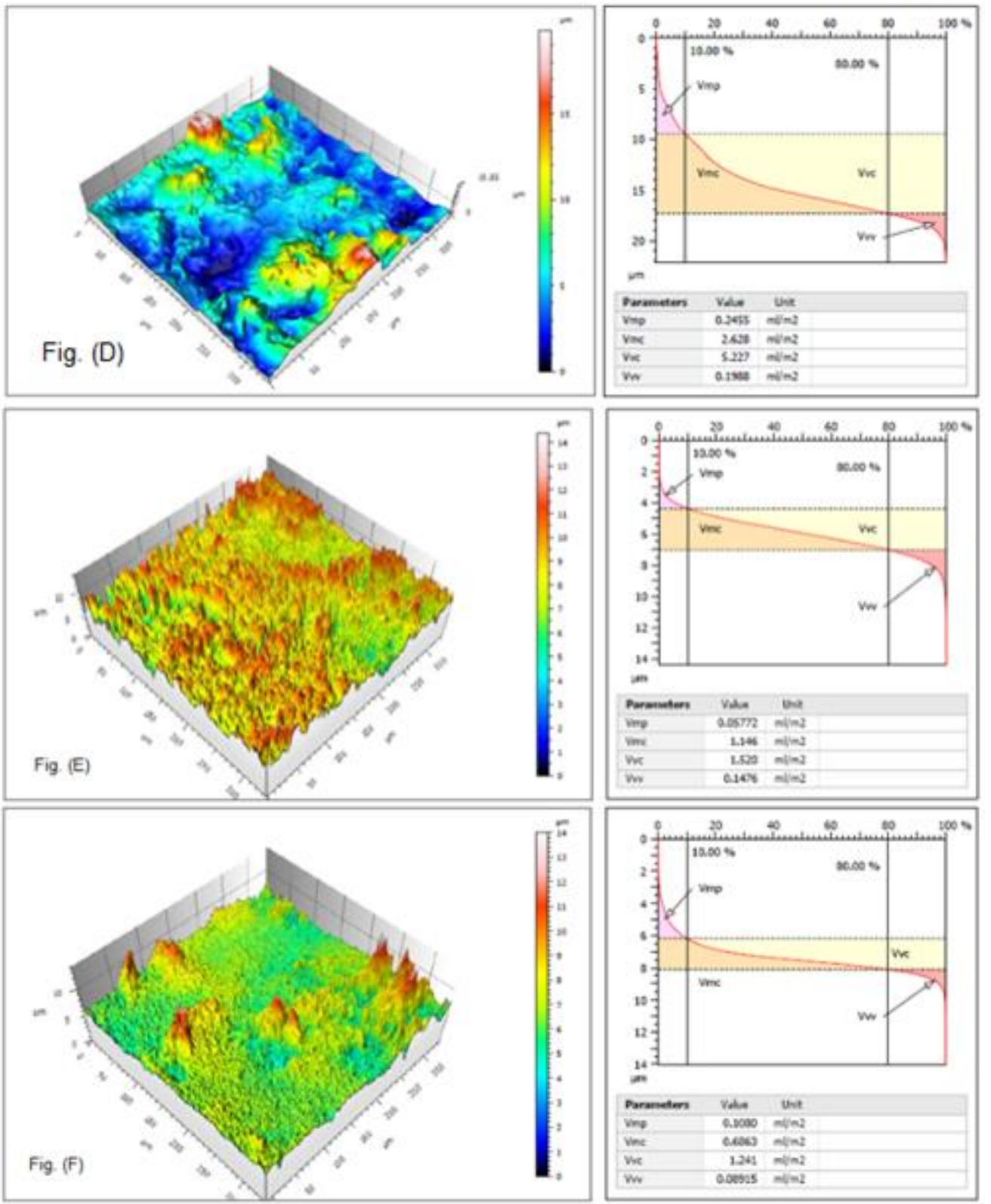

Figure 8: 3D roughness topology of the surface WRC/WRU and Abbot-Firestone curves

The current results of this preliminary research show, despite not allowing a clear resolution of wear mechanisms predominant, it was possible to compare both WRU and WRC chromed roll surfaces. Taking into account that the tribological system that is being analyzed (for pure slip and boundary lubrication conditions), the parameters show the greatest influence can be summarized in Table III:

Table III - Results of the surface topology (Figure 08)

\begin{tabular}{c|ccccc|ccccc}
\hline Parameter & \multicolumn{5}{|c|}{ WRU $\left(\mathrm{ml} / \mathrm{m}^{2}\right)$} & \multicolumn{5}{c}{ WRC $\left(\mathrm{ml} / \mathrm{m}^{2}\right)$} \\
\hline \hline- & $20 \mathrm{~km}$ & $50 \mathrm{~km}$ & $100 \mathrm{~km}$ & Std. Dev. & Variation & $20 \mathrm{~km}$ & $250 \mathrm{~km}$ & $500 \mathrm{~km}$ & Std. Dev. & Variation \\
\hline Vmp & 0,1623 & 0,1386 & 0,1202 & 0,021 & $-0,04$ & 0,2455 & 0,057 & 0,108 & 0,098 & $-0,14$ \\
Vmc & 2,053 & 2,166 & 2,44 & 0,199 & 0,39 & 2,628 & 1,146 & 0,6863 & 1,015 & $-1,94$ \\
VVc & 2,939 & 3,106 & 3,636 & 0,364 & 0,70 & 5,227 & 1,52 & 1,42 & 2,170 & $-3,81$ \\
Vvv & 0,2414 & 0,2302 & 0,2223 & 0,010 & $-0,02$ & 0,1988 & 0,1476 & 0,089 & 0,055 & $-0,11$ \\
\hline
\end{tabular}

From Table III, WRC surface parameters show a greater volume of "peaks", above the material "core" and a smaller volume of "valleys" under the same material "core", 
when compared to the no-chromed work rolls, as shown by images of Figure 8 . Evaluating the main parameters separately we have:

a) Vmp: represent the volume of material located on the highest peaks of the surface which is removed during a wear process. The results from chromed work rolls (at 500 $\mathrm{km}=0.108 \mathrm{ml} / \mathrm{m}^{2}$ ) in relation to no-chromed work rolls (at $100 \mathrm{~km}=0.1202 \mathrm{ml} / \mathrm{m} 2$ ), probably due high wear resistance from Hard chrome plating and, hence, hard coating reduced wear and increasing quantity of peaks to support the roughness during rolling trials. Confirming good performance of five times the increase in roll change of the no-chromed as compared to chromed work rolls, as shown by Figures 3 and 7[11]. The increase of resistance to surface roughness change determined the performance of work roll. Abrasive wear occurs by abrasion scratches of work roll after campaign while work roll mark is probably to be associated with low hardness and microstructure.

b) Vmc: reduction in volume of valleys in chromed work rolls (at $500 \mathrm{~km}$ ), indicating that Cr-layer contributes to area sustaining rolling load and, after a certain "milage", the effect is over. This might be related to loss/ wear out of $\mathrm{Cr}$ layer during the campaign in Cold Mill. For no-chromed work rolls, the volume of "valleys" after 100 km was nearly constant, as shown by Figure 8[11].

c) Vvv: For both chromed work rolls and no-chromed work rolls there was a reduction in void volume of the valleys. This may be related to decrease in amount of lubricant retention in the deepest valleys of the surface. This parameter is not affected by wear processes applied on the surface. However, chromed work rolls presented a five fold improvement when compared to no-chromed work rolls, therefore confirming Cr-layer in increasing this parameter, as shown in Figure 7 [11].

\section{CONCLUSION}

The 3D roughness parameters relevant for discriminating different topographies with regard to a specific application, the results of this work revealed:

1) Vmc parameter (the Core Material Volume - defined as volume of material comprising the texture between heights corresponding to the material ratio values of $p=10 \%$ and $q=80 \%$ ) is the most relevant parameter to characterize the cold rolling process. This parameter allows understanding the mechanism of steel deformation during cold rolling and consecutive change of surface roughness after every rolling process.

2) Surface replica technique/methodology is reliable.

3) There is a Sa significant drop in Sa values in rolls and the sheet when comparing no-crhomed rolls in relation to chromed rolls. Therefore, no-chromed rolls showed lower roughness retention as compared to chromed rolls.

4) Explanations could be given through Vmp, Vmc and Vvv parameters (not excluding eventual other 3D surface parameters). It is important to point out methodology for monitoring simultaneously the evolution of roughness/surface texture of both work rolls and sheet roughness. 
5) There is clearly an increase in roll change - of about five times, although technical and environmental care should be taken during application of hard chrome layer.

\section{Acknowledgements}

Authors gratefully thank USP and CRC for technical support given to this work.

\section{REFERENCES}

1. Godwin, M.J., The use of hi-chrome rolls in cold Tandem and temper mills, British steel corporation 9, Albert embankment, Gb-London SE1 7SN, Contract No 7210.EA/807 (1.5.1981 - 31.12.1983)

2. Hilgenberg, k. "Investigation of the self-organising behavior of lases implanted tool surfaces". Kassel University, 2014. ISBN 978-3-86219-788-0 (print); ISBN 978-386219-789-7 (e-book); URN: http://nbn-resolving.de/urn:nbn:de:0002-37890.

3. Matthew H. LEAHEY, M.H. Replacement of hard chrome electroplating by tungsten carbide based high velocity oxygen fueled thermal spray, Rensselaer Polytechnic Institute Hartford, CT December 2009.

4. Li, Hongchun. "A study on wear and surface roughness of work roll in cold rolling". $\mathrm{PhD}$ thesis, School of Mechanical, Materials and Mechatronic Engineering, University of Wollongong, 2008. Htt://ro.uow.edu.au/theses/125.

5. De Chiffre, S. Christiansen, S. Skade, Advantages and Industrial Applications of Three-Dimensional Surface Roughness Analysis Institute of Manufacturing Engineering, Technical University of Denmark

6. Stout, K.J., et al. "The Development 01 Methods for the Characterization of Roughness in three dimensions", report EUA 15178 EN. EC Brussels, 1993, ISBN O704413132.

7. Stout, K.J., Sullivan, P.J., "The use of $3 d$ Topographic Analysis to determine the microgeometric transfer Characteristics of textured Sheet Surfaces through Rolling", Annals of the CIRP, v.41, p.621-624, 1991.

8. PAWELSKI, O.; RASP, W.; ZWLCK, W.; NETTELBECK, H.-J.; STEINHOFF, K. "The influence of different work roll texturing systems on the development of surface structure in the temper rolling process of steel sheet used in the automotive industry". Journal of Materials Processing Technology, v. 45, p. 215-222, 1994.

9. OLIVEIRA, A. F. Private communication on Jun 2013. Usiminas Cubatão Brazil. 10. Simão, J.; Aspinwall, D. K., "Hard chromium plating of EDT mill work rolls". Journal of Materials Processing Technology, v. 92-93, p. 281-287, 1999, ISSN 09240136.

11. NUNES, Eduardo, et al. "Inter-Relationship among Skin Pass Reduction, 3D and 2D Roughness Parameters and the Stampability/Paintability of Cold Rolled Steel Sheets for the Automotive Industry: A Preliminary Analysis" [doi:10.4028/www.scientific.net/MSF.783-786.1039]. Materials Science Forum [online], v. 783-786, p. 1039-1045, 2014.

12. LEITE, M.V., SANTOS, M. M., MELLO, J. D. B., LIMA, A. G., RAMOS, G. P., MACHADO, J. R., SANTOS, N. L., ROSARIO, C. S., OLIVEIRA, A. F., RAMPINELLI, M. E. G., ROCHA, S. S., FERREIRA, R. L. O., LESSA, R. A. G. "Mecanismos de desgaste de cilindros de trabalho dos laminadores tandem de tiras a frio do Brasil". In: 48 Seminário de Laminação, Processos e Produtos Laminados e Revestidos, 2011, Santos. Semin. ABM, 2011; Seminário de laminação processos e produtos 
laminados e revestidos, 48; Seminário de Laminação, 48. São Paulo: ABM, 2011. p. 728-738.

13. OLIVEIRA, A. F. "Caracterização de um aço IF após relaminação no laminador de encruamento". 2009. Dissertação (Mestrado em Engenharia Metalúrgica e de Materiais) - Escola Politécnica, Universidade de São Paulo, São Paulo, 2009. Available in: http://www.teses.usp.br/teses/disponiveis/3/3133/tde-11082010$161554 /$. 